\title{
Disc electrophoretic study of seed proteins of various Medicago species, Melilotus albus, Trifolium pratense, and T. repens
}

\author{
J. PRZYBYLSKA and J. HURICH
}

Institute of Plant Genetics, Polish Academy of Sciences, Poznań, Poland

(Received: May 6, 1971.)

Abstract:

Disc electrophoretic study covered albumins, globulins and urea-treated globulins of seeds of 12 Medicago species, Melilotus albus, Trifolium pratense and T. repens. The electrophoretic data differentiated most of the examined Medicago species and indicated M. lupulina to be especially distinct. Some similarities of M. lupulina to Melilotus and Trifolium have been pointed out.

\section{INTRODUCTION}

Data provided by biochemical and chemical studies resulted in an increased interest in chemotaxonomic investigations. The employment of different chemical data in systematic studies is being largely stimulated by rapid development of relatively quick and simple analytical procedures. Also, the emphasis given recently to proteins as taxonomic characters is partly a consequence of developing the appropriate methods of analysis.

Disc electrophoresis belongs to the methods widely employed nowadays to compare the properties of proteins (see reviews: Steward, Barber 1964; Boulter, Thurman, Turner 1966; Boulter, Thurman 1968; Fairbrothers 1968, 1969, Johnson 1969). As pointed out by Boulter and Thurman (1968), "the method is highly feasible technically in its application in systematic surveys since it is quick, simple and inexpensive to use".

The subject of the present study is to compare disc electrophoretic patterns of seed proteins of chosen Medicago species and of the species representing related genera Melilotus and Trifolium. The investigations intend to check whether this approach may be useful in attacking taxonomic problems of the genus Medicago. There are controversial opinions concerning classification of this group which comprises about fifty species largely differing in morphology and geographical distribution (Sinskaja 1950).

The electrophoretic analysis covers albumins, globulins and urea-treated globulins. Albumins were electrophorizesi in basic buffer system only, while untreated 


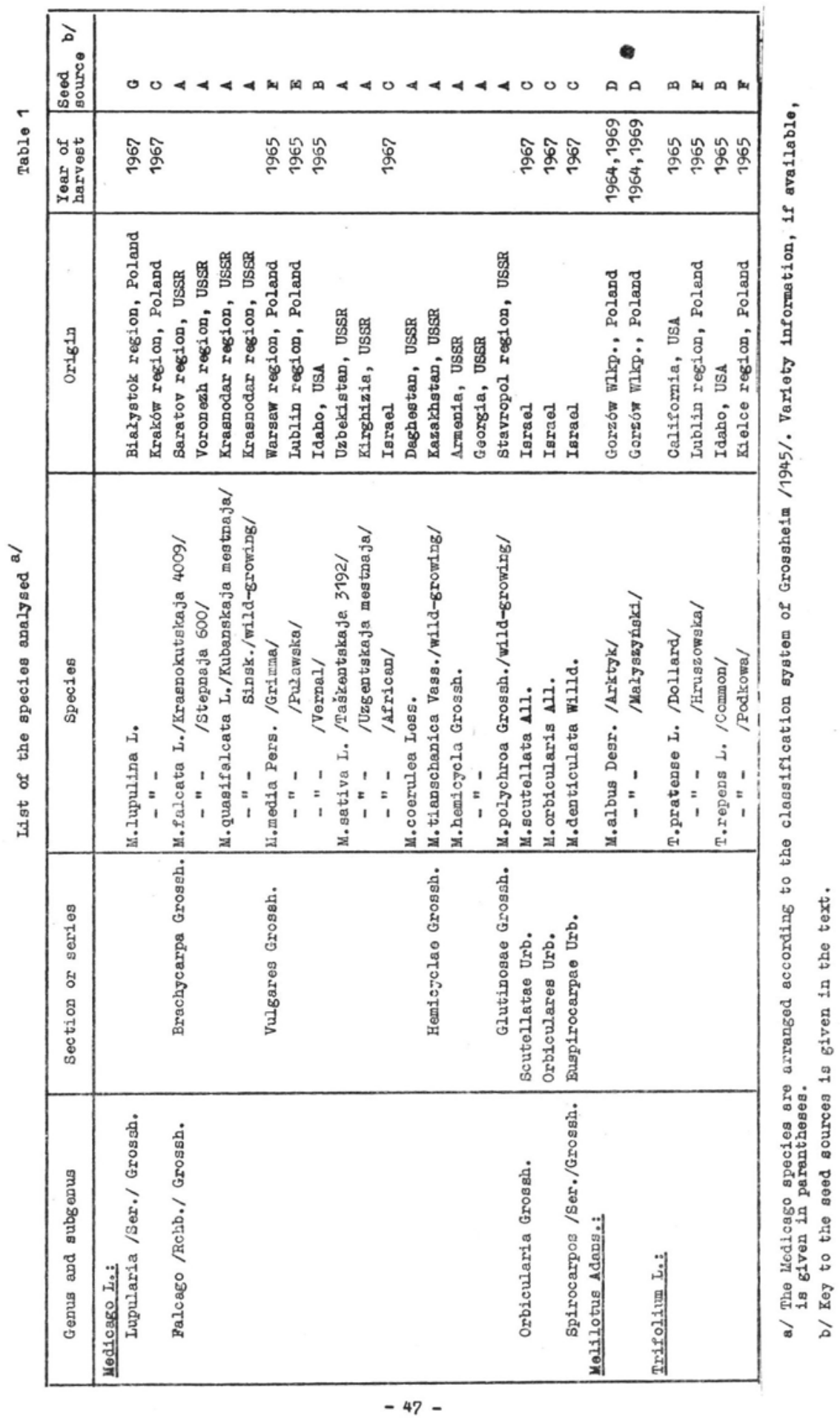


and urea-treated globulins were subjected to electrophoresis in both basic and acidic systems. Such a complex analysis, as most informative, has been suggested by results of the previous methodical studies covering several Medicago species (Przybylska, Hurich 1971).

\section{MATERIAL AND METHODS}

\section{Plant material}

The object of studies consisted of seeds of 12 Medicago species, 2 Trifolium species and of Melilotus albus. Some of the examined species were represented by seed samples originating from different sources and/or from different years of harvest. In total 28 seed samples were analysed; the samples are listed in table 1.

Following are the seed sources:

A - All-Union Institute of Plant Industry, Leningrad, USSR.

B - U.S. Department of Agriculture, ARS, New Crops Research Branch, Washington, USA.

C - Institute of Plant Breeding and Acclimatization, Radzików near Warsaw, Poland.

D - Institute of Soil Science and Cultivation of Plants, Gorzów Wlkp., Poland.

E - Institute of Soil Science and Cultivation of Plants, Puławy, Poland.

F - Plant Breeding Stations, Poland.

G - "Centrala Nasienna" (Seed Association), Poznań, Poland.

No attempt was made by the authors to check the identity of seed samples.

\section{Analytical procedures}

Electrophoretic analysis covered albumins, globulins and urea-treated globulins. The protein fractions were obtained as described in the previous paper (Przybylska, Hurich 1971).

Electrophoresis of proteins was performed on polyacrylamide gel. All protein fractions examined were electrophorized in tris-glycine buffer $\mathrm{pH} 8.3$ (Davis 1964), while untreated and urea-treated globulins were likewise subjected to electrophoresis in acetic acid- $\beta$-alanine buffer pH 4.5 (Reisfeld, Lewis, Williams 1962). Gels were stained with aniline blue black.

Protein contents in the extracts were determined by the method of Lowry et al. (1951), as modified by Miller (1959).

Detailed description of the procedure has been presented in the previous paper (Przybylska, Hurich 1971).

\section{Interpretation and presentation of results}

$R_{p}$ value of individual band on each diagram represents mean $R_{p}$ value calculated from six similar gels obtained from two extractions and three electrophoretic runs. Selected protein patterns have been also recorded photographically and by means 
of densitometric tracings, electrophoretic spectra being adjusted to equivalent migration velocities. The densitometric tracings were made with a Vitatron-densitometer, type No UFD 500; a filter with a maximum transmittance at $576 \mathrm{~m} \mu$ was used. Percentage similarity between two taxa was calculated according to Whitney et al. (1968) as:

No. of pairs of similar bands

No. of different bands + No. of pairs of similar bands

Percentage similarities were calculated for albumins and for globulins. In case of globulins, both basic and acidic gels were used for the calculations.

\section{RESULTS}

To check whether protein patterns of the taxa investigated vary with source of the material or year of harvest different seed samples were analysed for some of the examined species (see Table 1). In no case samples of the same species differed in respect to electrophoretic protein patterns though they varied in the total protein leve1.

While comparing electrophoretic patterns of seed proteins of the examined Medicago species it was observed that the corresponding spectra of $M$. media, $M$. sativa, $M$. hemicycla and $M$. polychroa were indistinguishable. Protein patterns of $M$. sativa, as of a representative of the above mentioned species, are shown in form of diagrams (see Fig. 1 and 2) and in form of photographs and densitometric tracings of the gels (see Fig. 3 and 4). Similar protein patterns were afforded by M. falcata, M. quasifalcata, M. tianschanica and M. coerulea. Concerning qualitative differences, $M$. falcata was distinguished by one additional globulin band revealed in basic buffer system $\left(R_{p} 0.81\right)$, while, in the same system, M. quasifalcata exhibited two additional globulin bands $\left(R_{p} 0.71 ; 0.81\right)$ (see Fig. 1$)$. M. tianschanica differed from $M$. sativa by the lack of one band on basic gels of albumins and of urea-treated globulins - protein band at $R_{p} 0.81$ was not detected in any of these fractions.

Medicago scutellata, $M$. orbicularis and $M$. denticulata varied significantly in their protein patterns which differed also remarkably from those of the above eight species. The qualitative and quantitative differences could be observed in albumin and in globulin fractions. Regarding globulins, essential differences were likewise revealed after urea-treatment (see Fig. 1 and 2).

Fig. 1. Diagrams of basic gel patterns of albumins (A), globulins (G), and urea-treated globulins (GU) from seeds of various Medicago species, Melilotus albus, Trifolium pratense, and T. repens. Abbreviations for taxa: ML, Medicago lupulina; MF, M. falcata; MQ, M. quasifalcata; MS, M. sativa; MT, M. tianschanica; MSc, M. scutellata; MO, M. orbicularis; MD, M. denticulata, MeA, Melilotus albus; TP, Trifolium pratense; TR, T. repens. Legend as for Fig. 2. 

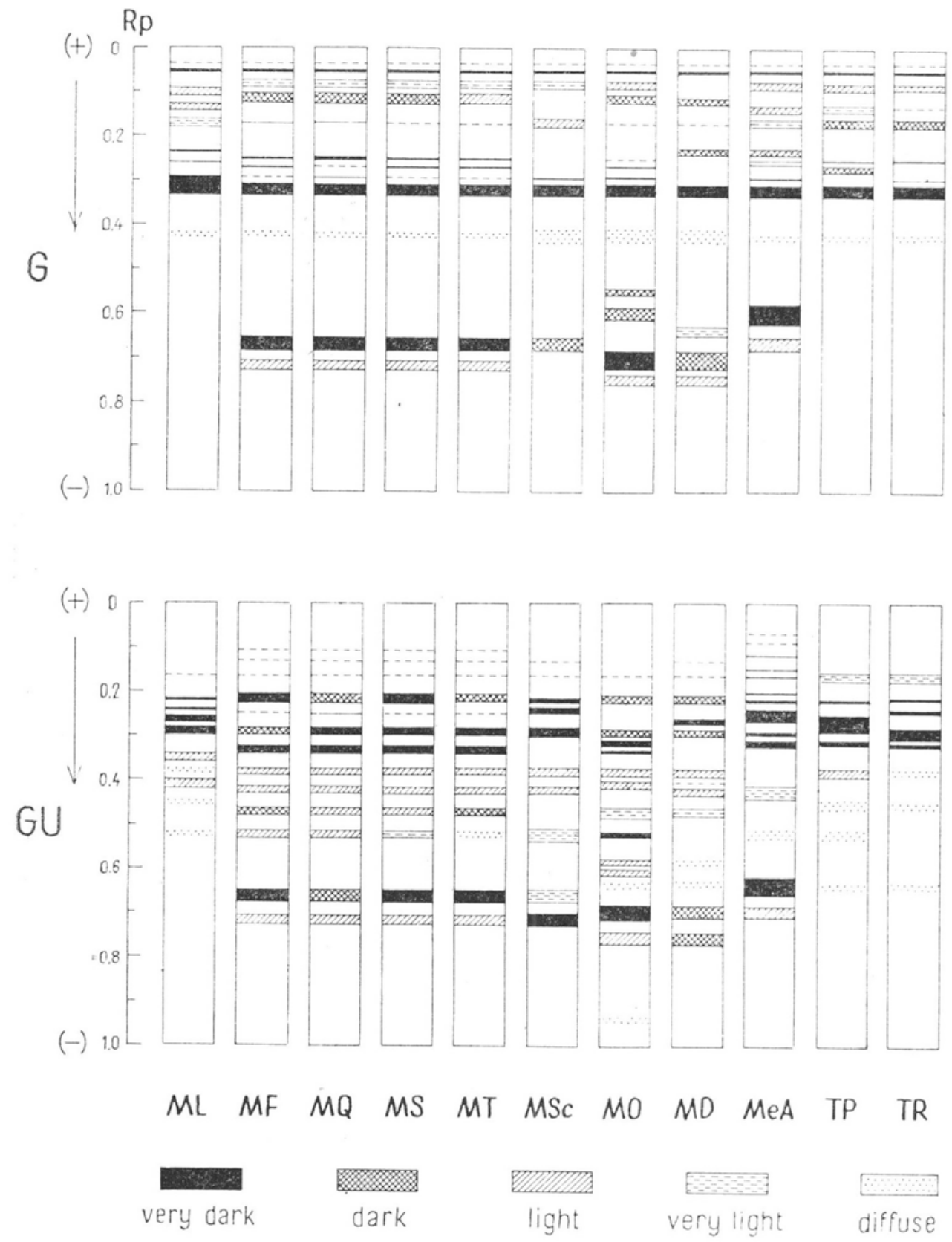

Fig. 2. Diagrams of acidic gel patterns of globulins (G) and urea-treated globulins (GU) from seeds of various Medicago species, Melilotus albus, Trifolium pratense and T. repens. 
Medicago lupulina showed to be especially distinguished from among the examined Medicago species. The differences in electrophoretic patterns could be observed in every protein fraction analysed which is illustrated in figures 1 and 2. Albumin gels revealed more bands, fast-moving ones $\left(R_{p} 0.93 ; 0.97 ; 1.0\right)$ being especially characteristic of the species. As regards globulins, bands of high $R_{p}$ values - observed in all the remaining Medicago species under study - have not been detected either in basic or in acidic buffer system (see Fig. 1 and 2). Moreover, electrophoretic patterns of urea-treated globulins of $M$. lupulina were qualitatively different - independently on the buffer system applied - from corresponding patterns of other Medicago species examined (see Fig. 1 and 2). Seed protein patterns of M. lupulina, as compared with those of $M$. sativa, are presented in figures 3 and 4 in form of photographs and densitometric tracings of the gels.

The analysed Trifolium species, $T$. pratense and $T$. repens, differed qualitatively one from another in globulin fraction only, the differences being observed in both buffer systems applied (see Fig. 1 and 2).

When comparing overall protein patterns of the analysed Medicago species and those of Melilotus albus, Trifolium pratense and $T$. repens, it may be observed that differences at the generic level do not exceed variations at the level of species (see Fig. 1 and 2). Moreover, it may be noticed that $M$. lupulina is more closely related - in respect to electrophoretic patterns of seed proteins - to Melilotus and Trifolium than to other Medicago species under study. Two of the fast-moving albumin bands characteristic of $M$. lupulina $\left(R_{p} 0.93 ; 1.0\right)$ were found in Melilotus and Trifolium while lack of fast-moving globulin bands was a common feature of $M$. lupulina and Trifolium. Electrophoretic patterns of urea-treated globulins of $M$. lupulina were more similar to corresponding patterns of Trifolium species and of Melilotus albus than to those provided by other Medicago species examined.

The relationships among the investigated taxa, expressed as percentage similarities between seed albumins and globulins, are shown in figures 5 and 6 . The values provide another kind of illustration of the above presented similarities and differences among the analysed species.

Identity of seed protein patterns of Medicago sativa, M. media, M. polychroa and $M$. hemicycla is reflected in 100 per cent similarity between seed albumins and globulins of any two species of this group. Also, considerable similarity of protein spectra of the above species with those of $M$. falcata, $M$. quasifalcata, $M$. tianschanica and $M$. coerulea is well illustrated by high percentage of similarities which, depending on the protein fraction analysed, range from 80 to 100 per cent.

The percentage similarity between seed albumins and globulins of any one of the above mentioned Medicago species and corresponding fractions of M. scutellata, $M$. orbicularis or $M$. denticulata proved to be relatively low. The values reported show likewise seed protein patterns of, M. scutellata, M. orbicularis and $M$. denticulata to be different. As globulins were electrophorized in basic and acidic buffers, it could be observed that values expressing percentage similarities varied depending on the buffer system applied. 

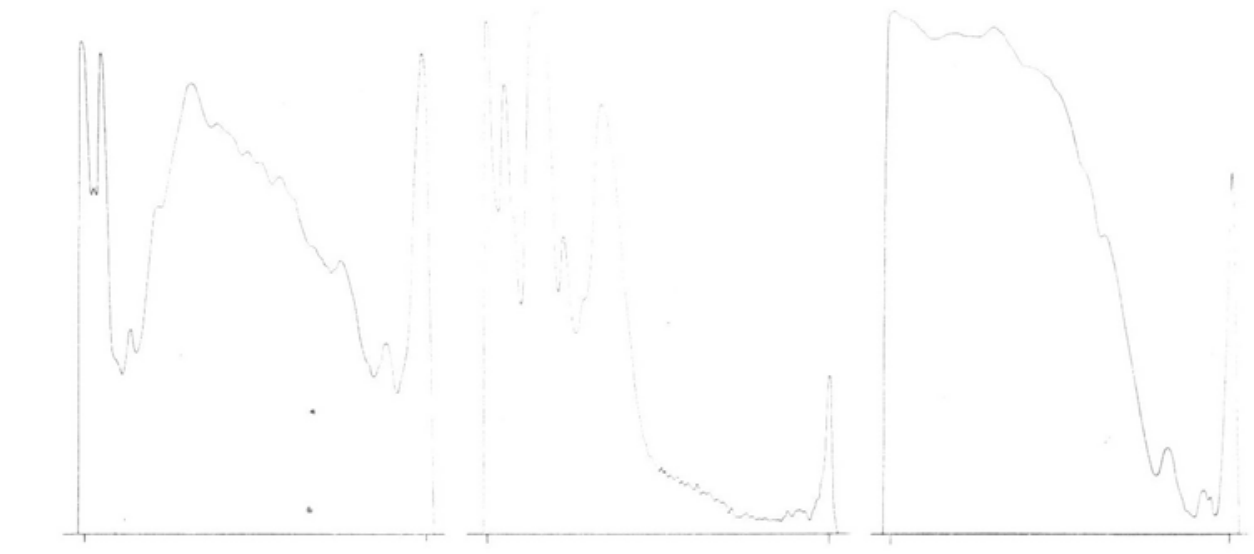

ML
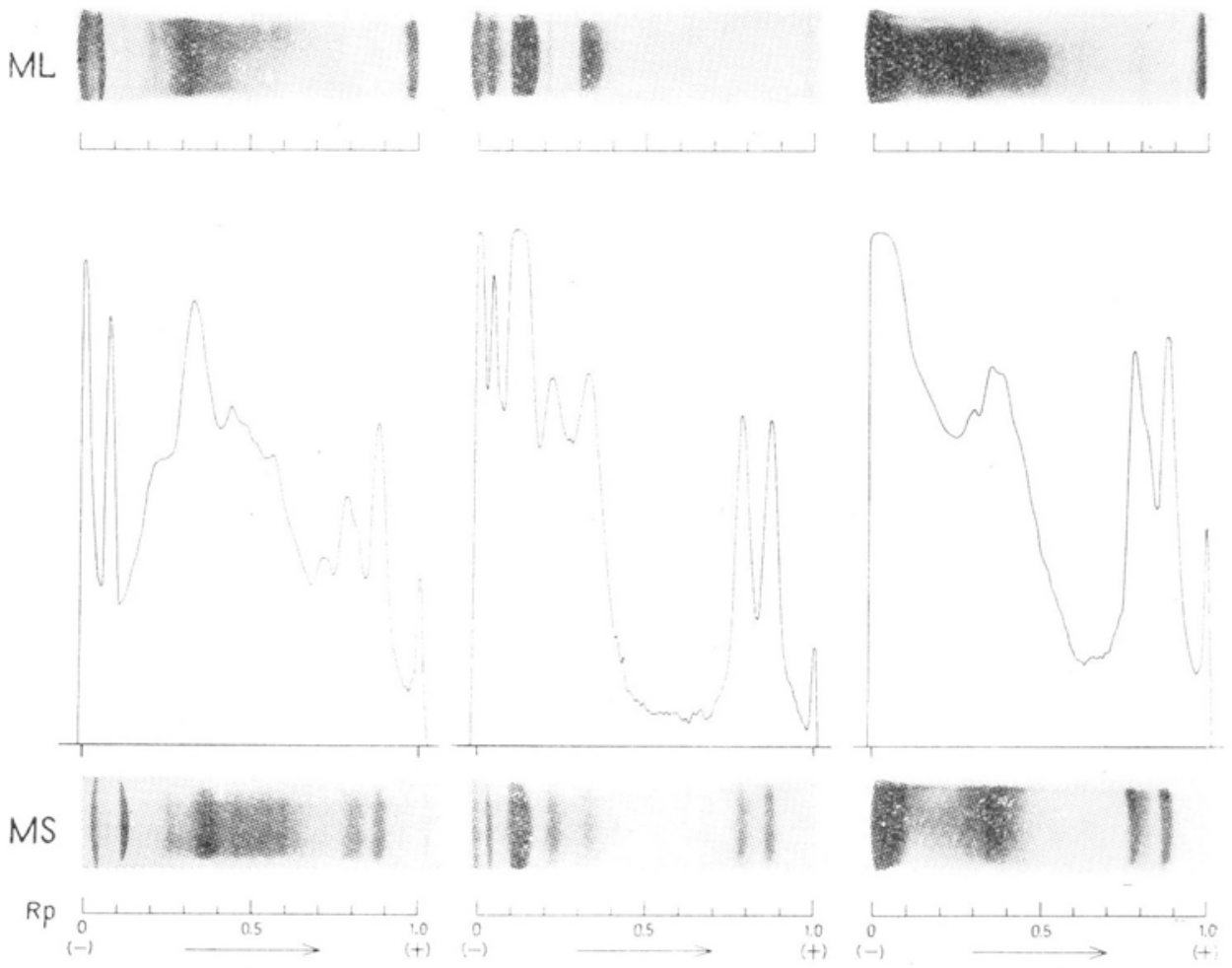

A

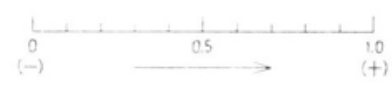

G

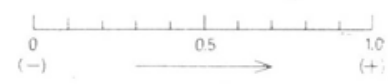

GU

Fig. 3. Photographs and densitometric tracings of basic gels of albumins (A), globulins (G), and urea-treated globulins (GU) from seeds of Medicago lupulina (ML) and M. sativa (MS).

Fig. 4. Photographs and densitometric tracings of acidic gels of globulins (G) and urea-treated globulins (GU) from seeds of Medicago lupulina (ML) and M. sativa (MS). 

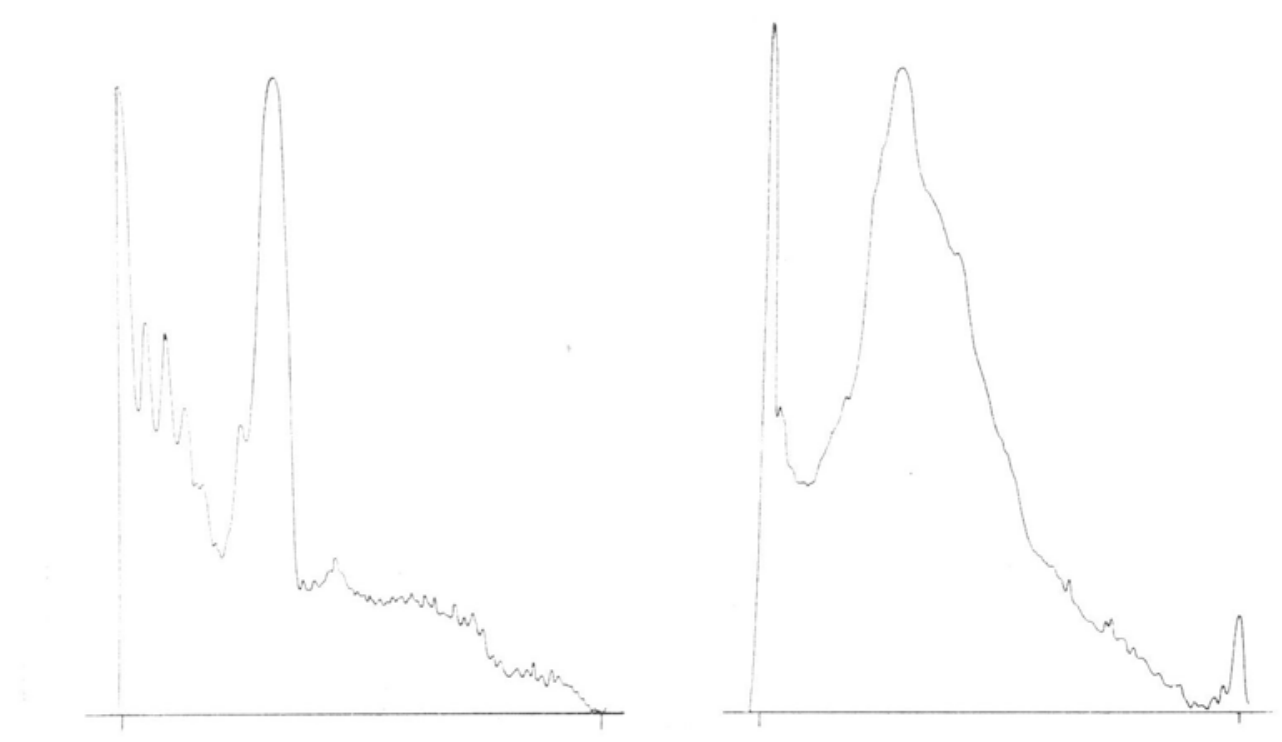

\section{ML || |}
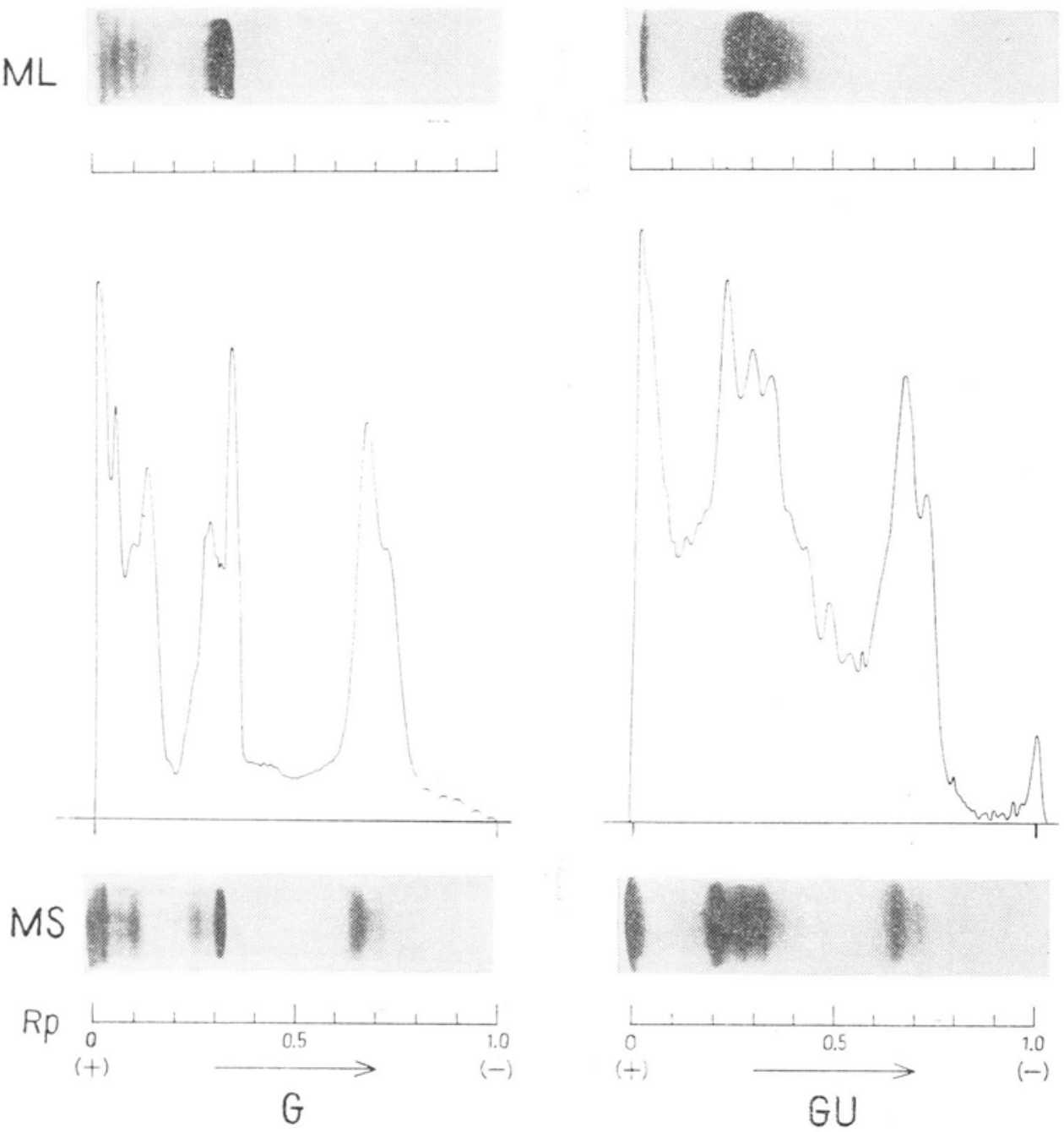

Fig. 4 
ALBUMINS

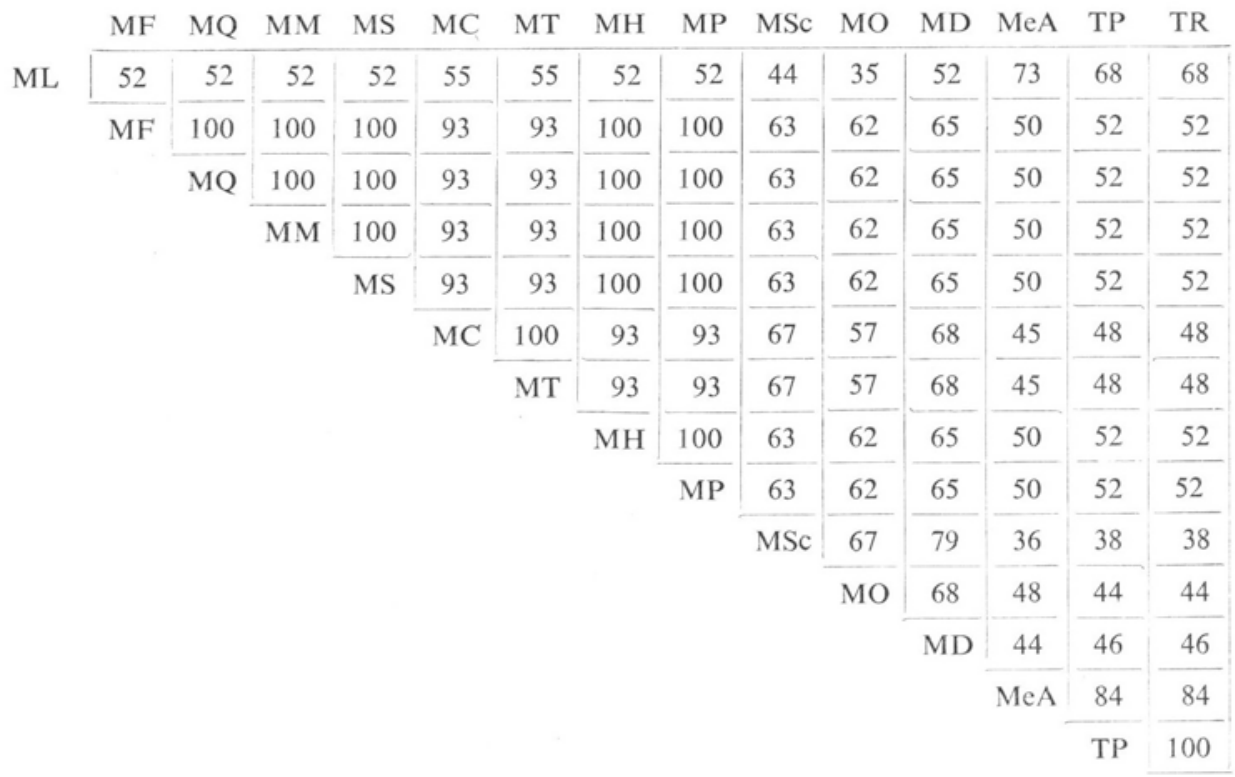

\section{GLOBULINS}

MF MQ MM MS MC MT MH MP MSc MO MD MeA TP

ML

\begin{tabular}{|c|c|c|c|c|c|c|c|c|c|c|c|c|c|}
\hline 45 & 42 & 50 & 50 & 50 & 50 & 50 & 50 & 50 & 36 & 33 & 50 & 75 & 50 \\
\hline \multirow[t]{13}{*}{ MF } & 90 & 89 & 89 & 89 & 89 & 89 & 89 & 55 & 31 & 38 & 33 & 45 & 40 \\
\hline & \multirow[t]{12}{*}{ MQ } & 80 & 80 & 80 & 80 & 80 & 80 & 64 & 29 & 36 & 31 & 42 & 36 \\
\hline & & \multirow[t]{11}{*}{$\mathrm{MM}$} & 100 & 100 & 100 & 100 & 100 & 60 & 23 & 42 & 36 & 50 & 44 \\
\hline & & & \multirow[t]{10}{*}{ MS } & 100 & 100 & 100 & 100 & 60 & 23 & 42 & 36 & 50 & 44 \\
\hline & & & & \multirow[t]{9}{*}{$\mathrm{MC}$} & 100 & 100 & 100 & 60 & 23 & 42 & 36 & 50 & 44 \\
\hline & & & & & \multirow[t]{8}{*}{ MT } & 100 & 100 & 60 & 23 & 42 & 36 & 50 & 44 \\
\hline & & & & & & \multirow[t]{7}{*}{ MH } & 100 & 60 & 23 & 42 & 36 & 50 & 44 \\
\hline & & & & & & & \multirow[t]{6}{*}{ MP } & 60 & 23 & 42 & 36 & 50 & 44 \\
\hline & & & & & & & & \multirow[t]{5}{*}{ MSc } & 23 & 55 & 46 & 50 & 44 \\
\hline & & & & & & & & & \multirow[t]{4}{*}{ MO } & 29 & 46 & 50 & 30 \\
\hline & & & & & & & & & & \multirow[t]{3}{*}{ MD } & 43 & 33 & 27 \\
\hline & & & & & & & & & & & \multirow[t]{2}{*}{$\mathrm{MeA}$} & 50 & 33 \\
\hline & & & & & & & & & & & & TP & 7 \\
\hline
\end{tabular}

Fig. 5. Percentage similarities among seed albumins and globulins of Medicago species, Melilotus albus, Trifolium pratense and $T$. repens - based on the basic gel patterns. 


\section{GLOBULINS}

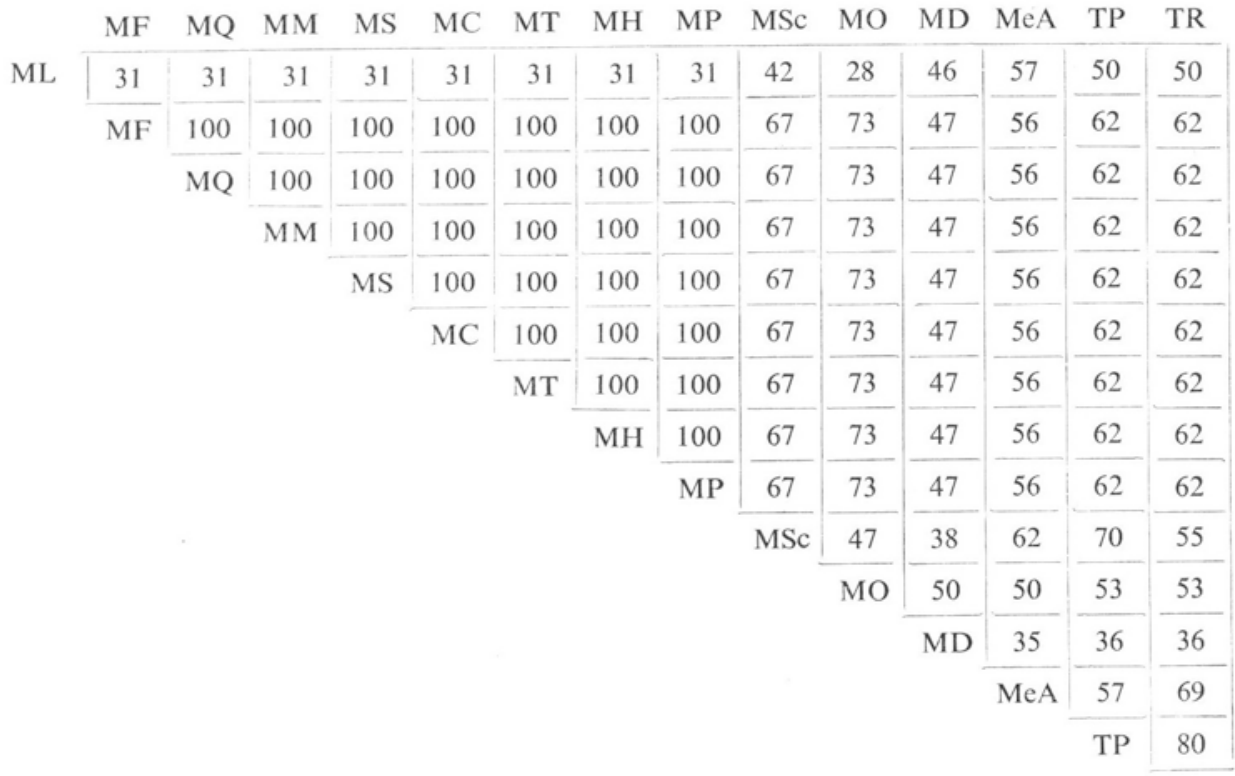

Fig. 6. Percentage similarities among seed globulins of Medicago species, Melilotus albus, Trifolium pratense and $T$. repens - based on the acidic gel patterns.

Abbreviations for taxa: ML, Medicago lupulina; MF, M. falcata; MQ, M. quasifalcata; MM, M. media; MS, M. sativa; MC, M. coerulea; MT, M. tianschanica; MH, M. hemicycla; MP, M. polychroa; MSc, M. scutellata; MO, M. orbicuiaris; $\mathrm{MD}, \mathrm{M}$. denticulata; MeA, Melilotus albus; TP, Trifolium pratense; TR, T. repens.

Low percentage similarity between $M$. lupulina and any other Medicago species analysed was found in case of both albumin and globulin fractions. Higher percentage similarities were recorded between protein patterns of $M$. lupulina on the one hand and those of Melilotus and Trifolium on the other.

\section{DISCUSSION}

Differentiation of the taxa investigated on the basis of electrophoretic patterns of seed proteins is in general consistent with that based on morphological features, i.e. with the existing classification presented in the Sinskaja's monograph of the genus (1950).

Piesent studies have indicated that Medicago species representing subgenus Falcago, namely $M$. falcata, M. quasifalcata, M. media, M. sativa, M. coerulea, $M$. tianschanica, $M$. hemicycla and $M$. polychroa, are similar or identical in respect 
to electrophoretic patterns of seed proteins. Such a situation could be expected, as subgenus Falcago comprises closely related perennial species among which intercrossing is rather commonly observed. The hybrid forms are greatly responsible for the lack of clear-cut morphological differences.

The examined annual Medicago species, M. orbicularis, $M$. scutellata and $M$. denticulata, afforded different protein patterns which is a gocd reflection of morphological differences among these species. M. orbicularis and $M$. scutellata, though belonging to the same subgenus Orbicularia, have been included in separate sections, distinct both in respect to morphological and physiological features, Orbiculares and Scutellatae, respectively. $M$. denticulata represents a separate subgenusSpirocarpos.

Results provided by gel electrophoresis of seed proteins indicated Medicago lupulina of subgenus Lupularia to be especially distinguished out of the examined Medicago species. In this connection unique taxonomic position of the subgenus Lupularia should be born in mind. The subgenus, comprising two species: $M$. $l u$ pulina and $M$. secundiflora, is morphologically so distinct from other members of Medicago that its placement within this genus has been repeatedly questioned by systematists (Sinskaja 1950; Heyn 1963).

The resemblance of protein patterns of Medicago lupulina to those of Melilotus and Trifolium fits to the opinions based on morphological features that subgenus Lupularia is more closely related to the above mentioned genera than other members of the genus Medicago.

Because of great variability in morphological and physiological features within Medicago, the genus has been suggested to be divided into two or more groups forming separate genera. Such a situation explains, to some extent, the remarkable differences in protein patterns among Medicago species.

Some of the results of the present investigations confirm the other authors' data coming from disc electrophoretic studies of seed proteins. Boulter and coworkers (1967) reported fast-moving globulin bands — undetected in Trifolium species to be characteristic of Medicago and Melilotus. This finding is essentially consistent with presently reported results. However, in the present studies, covering wider range of Medicago species, it was possible to show that $M$. lupulina is distinguished from among Medicago species by the lack of fast-moving globulin bands.

The distinct properties of seed proteins of Medicago lupulina have been likewise indicated by serological studies of Simon (1969). In result of these studies, covering 34 Medicago species, most of the examined species were found to be serologically homogeneous. It should be pointed out, however, that $M$. lupulina and $M$. secundiflora were distinctive. Moreover, serological data indicated remarkable affinity of M. lupulina to Melilotus. In consequence of these observations Simon has proposed reexamination of taxonomic position of the subgenus Lvpularia. The proposal is supported by presently reported results obtained from a different approach to comparative studies of proteins. 
The reported results provide further evidence that seed proteins may serve as plant characters of value for taxonomy. Electrophoretic patterns obtained showed to be constant, irrespective of the seed source, and provided basis for differentiation of the examined taxa which correlated in general with existing classification.

Species represented the lowest compared taxa in the present investigations as preliminary studies of several cultivated varieties of Medicago media did not show any differentiation. The lack of intervarietal differences might result from hybrid origin of seeds. It should be mentioned that inbred lines of Medicago media var. Vernal proved to be different in respect to albumin patterns (unpublished results).*

Differentiation of the investigated taxa was possible due to analysing different protein fractions and employing two buffer systems for electrophoretic separation of proteins. The advantage of such a broadened electrophoretic analysis has been already pointed out in the previous paper (Przybylska, Hurich 1971) and is confirmed by the present studies covering wider plant material. Qualitative differences between some of the examined taxa would not have been detected if both albumin and globulin fractions had not been analysed and two buffer systems applied. Electrophoretic analysis of urea-treated globulins yielded supplementary information on this fraction.

The literature data show that, depending on the plant material analysed, albumin or globulin fraction of seed proteins proves to be more informative in comparative studies. Gel electrophoretic studies of the seed proteins of Brassica and Sinapis species had shown that albumin patterns gave a better correlation with the established classification (Vaughan, Denford 1968). On the other hand, investigations carried out with numerous members of Leguminosae have indicated taxonomic value of globulin band patterns (Boulter, Thurman, Derbyshire 1967). In the present studies no preference of albumin or globulin patterns as taxonomic characters could be demonstrated, for the fractions supplied complementary data.

\section{SUMMARY}

Twelve Medicago species, Melilotus albus, Trifolium pratense and T. repens have been compared in respect to disc electrophoretic patterns of seed proteins. Some of the examined species were represented by seed samples originating from different sources. In total 28 seed samples were examined. The electrophoretic analysis covered albumins, globulins and urea-treated globulins. Albumins were electrophorized in basic buffer system, while untreated and urea-treated globulins were subjzcted to electrophoresis in both basic and acidic systems.

The electrophoretic data differentiated most of the examined Medicago species and indicated M. lupulina to be especially distinct. Some similarities of M. lupulina to Melilotus and Trifolium have been pointed out. Seed samples of individual species from different sources proved to be identical in respect to electrophoretic protein patterns.

The results obtained have been discussed with reference to the established classification. There have been also considered some methodical aspects of the studies.

*) Seeds of the inbred lines $\left(\mathrm{I}_{6}\right)$ were kindly supplied by Dr Z. Staszewski, Institute of Plant Breeding and Acclimatization, Radzików near Warsaw. 
The authors are indebted to J. George, Sc. B., for her skillful technical assistance.

This work was supported in part by a research grant from the U.S. Department of Agriculture.

\section{REFERENCES}

Boulter D., Thurman D. A., 1968, Acrylamide gelelectrophoresis of proteins in plant systematics [In:] Chemotaxonomy and Serotaxonomy, J. G. Hawkes ed., Academic Press, London, pp. $39-48$.

Boulter D., Thurman D. A., Derbyshire E., 1967, A disc electrophoretic study of globulin proteins of legume seeds with reference to their systematics, New Phytol. 66: 27-36.

Boulter D., Thurman D. A., Turner B. L., 1966, The use of disc electrophoresis of plant proteins in systematics, Taxon 15: 135-143.

Davis B. J., 1964, Disc electrophoresis - II. Method and application to human serum proteins, Ann. New York Acad. Sci. 121: 404-427.

Fairbrothers D. E., 1968, Chemosystematics with emphasis on systematic serology [In:] Modern Methods in Plant Taxonomy, V.H. Heywood ed., Academic Press, London, pp. 141-174.

Fairbrothers D. E., 1969, Comparisons of proteins obtained from diverse plant organs for chemosystematic research, Rev. Roum. Biochim. 6: 95-103.

Grossheim A. A, 1945, Medicago L. [In:] Flora URSS (Flora Unionis Rerumpublicarum Sovieticarum Socialisticarum ) t. 11, B.K. Schischkin ed., Edito Academiae Scientiarum URSS, Mosqua-Leningrad, pp. 129-175.

Heyn C. C., 1963, The annual species of Medicago [In:] Scripta Hierosolomytana, vol. 12, Magnes, Jerusalem. (Cyt. after Simon 1969).

Johnson B. L., 1969, The protein electrophoresis approach to species relationships in wheat, Genetics Lectures 1: 19-44.

Lowry O. H., Rosenbrough N. J., Farr A. L., Randall R. J., 1951, Protein measurement with the Folin phenol reagent, J. Biol. Chem. 193: 265-275.

Miller G. L., 1959, Protein determination for large numbers of samples, Anal. Chem. 31: 964.

Przybylska J., Hurich J., 1971, The use of basic and acidic gel systems in disc electrophoretic studies of seed proteins of some Medicago species, Bull. Acad. Polon. Sci., Ser. sci. biol. 19: 31-36.

Reisfeld R. A., Lewis U. J., Williams D. E., 1962, Disc electrophoresis of basic proteins and peptides on polyacrylamide gels, Nature 195: 281-283.

Simon J. P., 1969, Serological studies in Medicago, Melilotus, Trigonella, and certain other genera of the Leguminosae. I. Quantitative precipitin tests and immunodiffusion techniques, Bot. Gaz. 130: $127-141$.

Sinskaja E. N., 1950, Lucerna-Medicago L. EM. [In:] Kulturnaja flora SSSR, t. 13, vyp. 1, E.N. Sinskaja ed., Izd-vo Sel'skochoziajstvennoj Literatury, Moskva, pp. 7-339.

Steward F. C., Barber J. T., 1964, The use of acrylamide gel electrophoresis in the investigation of the soluble proteins of plants, Ann. New York Acad. Sci. 121: 525-531.

Vaughan J. G., Denford K. E., 1968, An acrylamide gel electrophoretic study of the seed proteins of Brassica and Sinapis species, with special reference to their taxonomic value, J. Exp. Bot. 19: 724-732.

Whitney P. J., Vaughan J. G., Heale J. B., 1968, A disc electrophoretic study of the proteins of Verticillium albo-atrum, Verticillium dahliae, and Fusarium oxysporum with reference to their taxonomy, J. Exp. Bot. 19: 415-426. 


\section{Analiza elektroforetyczna bialek nasion różnych gatunków Medicago, Melilotus albus, Trifolium pratense $i T$. repens przy pomocy elektroforezy na żelu poliakrylamidowym}

\section{Streszczenie}

W oparciu o elektroforetyczne obrazy białek nasion porównano dwanaście gatunków Medicago, Melilotus albus, Trifolium pratense i $T$. repens. Dla niektórych gatunków analizowano próby nasion pochodzące $\mathrm{z}$ różnych źródeł. Ogółem zanalizowano 28 prób. Elektroforezę przeprowadzano na żelu poliakrylamidowym. Analiza elektroforetyczna obejmowała albuminy, globuliny i globuliny traktowane mocznikiem. Albuminy rozdzielano elektroforetycznie w zasadowym układzie buforowym. Globuliny, nietraktowane oraz traktowane mocznikiem, poddawano elektroforezie zarówno w układzie zasadowym, jak i kwaśnym.

Dane elektroforetyczne wykazały zróżnicowanie większości badanych gatunków Medicago ujawniając szczególną odrębność M. lupulina. Zaobserwowano pewne podobieństwa obrazów białkowych M. lupulina w stosunku do obrazów Melilotus i Trifolium. Próby nasion poszczególnych gatunków pochodzące $\mathrm{z}$ różnych źródeł nie wykazały różnic w elektroforetycznych obrazach białkowych.

Uzyskane wyniki omówiono w nawiązaniu do stanowiska systematycznego badanych gatunków. W dyskusji uwzględniono również metodyczny aspekt badań. 